\title{
Preparation and evaluation of diclofenac sodium orally disintegrating tablets
}

\author{
Valeriu IANCU*, ${ }^{1}$ Florentina RONCEA, ${ }^{1}$ Radu George CAZACINCU, ${ }^{2}$ Dumitru LUPULEASA ${ }^{3}$ \\ ${ }^{1}$ Ovidius University of Constanta, Faculty of Pharmacy, 1 University Alley, Campus, Corp B, Constanta, \\ Romania \\ ${ }^{2}$ Magistra C\&C, 82A Aurel Vlaicu Blvd., Constanta, Romania \\ ${ }^{3}$ Carol Davila University of Medicine and Pharmacy, Faculty of Pharmacy, 6 Traian Vuia, Bucharest, Romania
}

\begin{abstract}
Orally disintegrating tablets (ODTs) are dosage forms which disintegrate in mouth within seconds without need of water. This type of quality in dosage form can be attained by addition of different varieties of excipients. Pharmaburst ${ }^{\mathrm{TM}} 500$ is a co-processed excipient system which allows rapid disintegration and low adhesion to punches. The aim of the present study was to develop and evaluate $25 \mathrm{mg}$ diclofenac sodium ODTs (orodispersible tablets) batches by direct compression method at different compression forces $10 \mathrm{kN}(\mathrm{F} 1)$ and 20 $\mathrm{kN}(\mathrm{F} 2)$ and directly compressible excipients used in different ratio (Avicel PH 102, magnesium stearate and coprocessed excipient Pharmaburst ${ }^{\mathrm{TM}} 500,70 \%$ and $\left.80 \% \mathrm{w} / \mathrm{w}\right)$. The obtained batches were analyzed for appearance, tablet thickness, uniformity of weight, hardness, friability, disintegration time, and non-compendial methods (wetting time). Co-processed Pharmaburst ${ }^{\mathrm{TM}} 500$ excipient $70 \%$ used for sodium diclofenac ODT obtaining determined good results for quality control tests evaluation.
\end{abstract}

Keywords: orally disintegrating tablets, Pharmaburst ${ }^{\mathrm{TM}} 500$, diclofenac sodium direct compression, quality control tests.

\section{Introduction}

The development and implementation of rapidly disintegrating tablets in the buccal cavity will widen the possibilities of pharmacotherapy, particularly the need to use medicines in emergencies and drugs that are extensively metabolized in the liver [1].

A large majority of the new chemical entities and many new existing drug molecules are poorly soluble, thereby limiting their potential uses and increasing the difficulty of formulating bioavailable drug products, so lastly the purpose of this study was to increase diclofenac sodium dissolution using fast dissolving tablets [2].

Regarding Biopharmaceutics Classification System (BCS), high permeability and low solubility drugs are grouped in class II. In this case, the dissolution profile must be quite definite and highly reproducible. Drug dissolution of this class is the limiting step for drug absorption. Although it has excellent bioavailability (99\%), its poor aqueous solubility makes absorption and dissolution ratelimited, thus delaying onset of action [3].

Diclofenac sodium (o-(2,6-dichloroanilino) phenyl)acetic acid sodium salt is a nonsteroidal antiinflammatory drug (NSAID) taken or applied to reduce inflammation and as an analgesic, reducing pain in certain conditions. It is a faintly yellowish white to light beige, virtually odorless, slightly hygroscopic crystalline powder. It is freely soluble in methanol, soluble in ethanol, sparingly soluble in water and practically insoluble in chloroform and in dilute acid [4] with a pKa $=4.0 \pm 0.2$ at $25^{\circ} \mathrm{C}$ in water, and a biological half-life time $\left(t_{1} / 2\right)$ of $1.2-2$ hours (35\% of the substance is entero-hepatic recycled). Diclofenac sodium is $100 \%$ absorbed after oral administration compared to i.v. administration, as measured by urine recovery. However, due to firstpass metabolism, only about $50 \%$ of the absorbed dose is systemically available $[5,6]$.

Pharmaburst $^{\mathrm{TM}} 500$ appears as a yellowishwhite powder, with apparent density $0.31-0.51 \mathrm{~g} / \mathrm{mL}$, real density $0.38-0.68 \mathrm{~g} / \mathrm{mL}$ and total content in polyols 73.8-93.8\%. Pharmaburst is a mixture of coprocessed excipients: crospovidone, mannitol, sorbitol and silicon dioxide precipitate or Aerosil 200, exhibiting excellent flow characteristics, can be directly compressed at normal conditions of temperature and humidity that is devoid of product adherence to punch faces. It is easy to use and has the ability to dissolve rapidly. It presents an efficient cost, it is easy to formulate with active substances of choice, in order to achieve rapid dissolving dosage forms [7].

Pharmaburst ${ }^{\mathrm{TM}} 500$ was specifically developed for optimal performance in terms of robustness 
(compaction and friability), superior organoleptic characteristics, and fast disintegration time.

The scientific novelty of our study consists in using a co-processed excipient in the formulation of orodispersible tablets with NSAID, which allows the use without restrictions or requirements for royalty payments for ODT technologies protected by patents. The co-processing of Pharmaburst ${ }^{\mathrm{TM}} 500$ is designed to improve the internal porosity of the platform constituent particles, which allows for more rapid liquid penetration into the tablet matrix, reducing disintegration time, but also reduces the compressibility of the material. Pharmaburst ${ }^{\mathrm{TM}} 500$ makes tablets with high active principle ingredient drug loading (up to $750 \mathrm{mg}$ of active principle) without the need for additional binders, allows low adhesion to punches, smooth and creamy, and helps to mask taste and grittiness of the active principle, highly compatible, rapid disintegration and costeffective [8].

\section{Experimental}

A biopharmaceutical and pharmacokinetic analysis of the drug substance was made in order to argue the elaboration of orodispersible tablets with diclofenac sodium. There were collected the values of the structural - molecular parameters and the biopharmaceutical and pharmacokinetic properties of substances from bibliographical sources. Based on these data the capacity at different levels of orogastrointestinal tract was evaluated [9].

For a good bioavailability (absorption and permeability) of drug substances, the molecular structural data must be within the limits shown in Table 1 (Rule of Lipinski or Rule of the five) [10].

Table 1. The molecular structural data of diclofenac sodium [4].

\begin{tabular}{|l|c|c|c|}
\hline & Parameters & Values & Lipinski \\
\hline 1. & Molecular mass & $\begin{array}{c}318,130 \\
\mathrm{Da}\end{array}$ & $<500 \mathrm{Da}$ \\
\hline 2. & $\begin{array}{c}\text { The surface area of the } \\
\text { polar molecule }\end{array}$ & $\begin{array}{c}49,33 \\
\AA^{2}\end{array}$ & $<140 \AA^{2}$ \\
\hline 3. & $\begin{array}{c}\text { The amount of proton } \\
\text { donors }\end{array}$ & 1 & $<5$ \\
\hline 4. & $\begin{array}{c}\text { The amount of proton } \\
\text { acceptors }\end{array}$ & 3 & $<10$ \\
\hline 5. & $\begin{array}{c}\text { Total number of } \\
\text { rotation connections } \\
\text { (flexibility of the } \\
\text { molecule) }\end{array}$ & 4 & $<10$ \\
\hline
\end{tabular}

Examining the molecular structural data of diclofenac sodium, we can conclude that they fall within the limit values according to C.A. Lipinski's rule. Thus, the administration of this oral preparation wouldn't create problems of absorption and intestinal permeability.
For obtaining orodispersible tablets with $25 \mathrm{mg}$ diclofenac sodium we have used the direct compression method at different compression forces 10 and $20 \mathrm{kN}(\mathrm{F} 1$ - F2) and directly compressible excipients used in different ratio (Avicel PH 102, magnesium stearate and co-processed excipient Pharmaburst $^{\mathrm{TM}} 50070 \%$ and $80 \%$ w/w) (Table 2) [11].

Table 2. The composition of diclofenac sodium orodispersible tablets.

\begin{tabular}{|c|c|c|c|}
\hline \multirow{2}{*}{$\begin{array}{l}\text { Name of } \\
\text { substance }\end{array}$} & \multicolumn{2}{|c|}{ Quantity (mg) } & \multirow{2}{*}{$\begin{array}{l}\text { Role in } \\
\text { formulation }\end{array}$} \\
\hline & $\begin{array}{c}\mathrm{F} 1 \\
(10 \mathrm{kN})\end{array}$ & $\begin{array}{c}\mathrm{F} 2 \\
(20 \mathrm{kN})\end{array}$ & \\
\hline $\begin{array}{l}\text { Diclofenac } \\
\text { sodium }\end{array}$ & 25 & 25 & $\begin{array}{l}\text { Active } \\
\text { principle } \\
\text { ingredient }\end{array}$ \\
\hline $\begin{array}{l}\text { Pharmaburst }{ }^{\mathrm{TM}} \\
500\end{array}$ & 98 & 112 & $\begin{array}{l}\text { Co- } \\
\text { processed } \\
\text { excipient }\end{array}$ \\
\hline $\begin{array}{l}\text { Avicel PH } \\
102\end{array}$ & 15.6 & 1.6 & Filler \\
\hline $\begin{array}{l}\text { Magnesium } \\
\text { stearate }\end{array}$ & 1.4 & 1.4 & Lubricant \\
\hline $\begin{array}{l}\text { Total mass/ } \\
\text { tablet (mg) }\end{array}$ & 140 & 140 & - \\
\hline
\end{tabular}

\section{Diclofenac sodium ODTs quality control evaluation}

Dimensional properties. Tablet thickness is an important characteristic in reproducing appearance and also in counting by using filling equipment. Some filling equipment utilizes the uniform thickness of the tablets as a counting mechanism. Ten tablets were taken and their thickness was recorded using a Dr. Schleuuniger Tablet Tester 8M on 10 tablets; values were expressed as mean \pm SD.

Uniformity of weight. Weight variation test is done with 20 tablets. It is the individual variation of tablet weight from the average weight of 20 tablets. None of the tablets deviated from the average weight by more than $\pm 7.5 \%$ [12].

Mechanical strength. The tablet hardness, which is the force required to break a tablet in a diametric compression force of the tablets, was measured using a Dr. Schleuuniger Tablet Tester 8M. Ten tablets from each formulation batch were tested randomly and the average reading noted $(\mathrm{N})[12]$.

Disintegration time. Disintegration time for ODTs was determined using Disintegration test system QC-21, one tablet being placed in each tube of disintegration apparatus (water as the disintegrating medium, $37 \pm 2^{\circ} \mathrm{C}$ ). Six tablets from each batch (formulation) were tested for the disintegration time calculations. To comply the test, all tablets should disintegrate within $1 \mathrm{~min}$. The time in seconds taken for the complete disintegration of the 
tablet with no palpable mass in the apparatus was measured in seconds [12].

Friability of the tablets. Tablet friability was measured using an Electrolab EF-2 friabilator at 25 rpm for $4 \mathrm{~min}$. The weight of 20 tablets before and after completion of the test was recorded and friability was calculated by the following formula [12]:

$\%$ Friability $=\frac{\text { initial weight }- \text { final weight }}{\text { initial weight }} \times 100$

Wetting time (non-compendial). The wetting time of the tablet was measured by placing 5 circular tissue papers ( $10 \mathrm{~cm}$ in diameter) in a Petri dish of 10 $\mathrm{cm}$ diameter. Water $(10 \mathrm{~mL})$ containing methylene blue $(0.1 \% \mathrm{w} / \mathrm{v})$ was added to the Petri dish. A tablet was carefully placed on the surface of the tissue paper and the time required for the dye to reach the upper surface of the tablet was recorded as wetting time (s). The measurements were carried out in triplicate [13]

\section{Results and Discussions}

Diclofenac sodium ODTs $25 \mathrm{mg}$ tablets had disk shape, white color, uniform look, intact edges, flat surface and this is related to the results for dimensional properties, tablet thickness, uniformity of weight from Table 3.

Table 3. Dimensional properties of $25 \mathrm{mg}$ diclofenac sodium orodispersible tablets.

\begin{tabular}{|c|c|c|c|c|}
\hline \multirow[t]{2}{*}{ Parameter } & \multicolumn{2}{|c|}{$\begin{array}{c}\text { F.1 70\% } \\
\text { Pharmaburst }^{\mathrm{TM}} 500\end{array}$} & \multicolumn{2}{|c|}{$\begin{array}{c}\text { F.2 80\% } \\
\text { Pharmaburst }^{\mathrm{TM}} \\
500 \\
\end{array}$} \\
\hline & $10 \mathrm{kN}$ & $20 \mathrm{kN}$ & $10 \mathrm{kN}$ & $20 \mathrm{kN}$ \\
\hline $\begin{array}{c}\text { Uniformity of } \\
\text { weight }(\mathrm{g})\end{array}$ & 0.1343 & 0.1376 & 0.1358 & 0.1326 \\
\hline $\begin{array}{l}\text { Thickness } \\
(\mathrm{mm}), \\
\text { mean } \pm \mathrm{SD}\end{array}$ & $\begin{array}{c}2.89 \\
\pm 0.159\end{array}$ & $\begin{array}{c}3.24 \\
\pm 0.147\end{array}$ & $\begin{array}{c}3.30 \\
\pm 0.133\end{array}$ & $\begin{array}{c}3.12 \\
\pm \\
0.120 \\
\end{array}$ \\
\hline $\begin{array}{c}\text { Diameter } \\
(\mathrm{mm}), \\
\text { mean } \pm \mathrm{SD}\end{array}$ & $\begin{array}{c}7.03 \\
\pm 0.015\end{array}$ & $\begin{aligned} & 7.05 \\
\pm & 0.009\end{aligned}$ & $\begin{array}{c}7.02 \\
\pm 0.005\end{array}$ & $\begin{array}{c}7.04 \\
\pm \\
0.020\end{array}$ \\
\hline
\end{tabular}

Table 4. Quality test results for $25 \mathrm{mg}$ diclofenac sodium orodispersible tablets.

\begin{tabular}{|c|c|c|c|c|}
\hline \multirow[t]{2}{*}{ Parameter } & \multicolumn{2}{|c|}{$\begin{array}{c}\text { F.1 70\% } \\
\text { Pharmaburst }^{\mathrm{TM}} \\
500\end{array}$} & \multicolumn{2}{|c|}{$\begin{array}{c}\text { F.2 80\% } \\
\text { Pharmaburst }^{\mathrm{TM}} \\
500\end{array}$} \\
\hline & $10 \mathrm{kN}$ & $20 \mathrm{kN}$ & $10 \mathrm{kN}$ & $20 \mathrm{kN}$ \\
\hline $\begin{array}{c}\text { Hardness }(\mathrm{N}), \\
\text { mean value }\end{array}$ & 123 & 84.3 & 100.2 & 64.1 \\
\hline Friability $(\%)$ & 0.74 & 1.48 & 1.65 & 3.34 \\
\hline $\begin{array}{c}\text { Disintegration } \\
\text { time }(\mathrm{s})\end{array}$ & 170 & 125 & 162 & 233 \\
\hline
\end{tabular}

The tablets from formula F1 obtained at $20 \mathrm{kN}$ and from $\mathrm{F} 2$ obtained at 10 and $20 \mathrm{kN}$ showed a high friability $(>1 \%)$, which refers to an inadequate resistance against abrasion, except formula I (0.74), obtained at $10 \mathrm{kN}$ (Table 4).
Table 5. Evaluation of the wetting and disintegration time of $25 \mathrm{mg}$ diclofenac sodium orodispersible tablets.

\begin{tabular}{|c|c|c|c|c|}
\hline \multirow{2}{*}{$\begin{array}{c}\text { Pharma- } \\
\text { burst }\end{array}$} & \multicolumn{2}{|c|}{$\begin{array}{c}\text { Compression } \\
\text { force } \\
\text { TM500 }\end{array}$} & \multicolumn{2}{c|}{$\begin{array}{c}\text { Compression } \\
\text { force }\end{array}$} \\
\cline { 2 - 5 } (w/w\%) & \multicolumn{3}{|c|}{ Tested parameters } \\
\cline { 2 - 5 } & $\begin{array}{c}\text { Wetting } \\
\text { time (s) }\end{array}$ & $\begin{array}{c}\text { Disinte } \\
\text { gration } \\
\text { time (s) }\end{array}$ & $\begin{array}{c}\text { Wetting } \\
\text { time (s) }\end{array}$ & $\begin{array}{c}\text { Disinte } \\
\text { gration } \\
\text { time (s) }\end{array}$ \\
\hline $70 \%$ & $\begin{array}{c}60 \pm \\
0.0966\end{array}$ & 170 & $\begin{array}{c}67 \pm \\
0.0570\end{array}$ & 125 \\
\hline $80 \%$ & $\begin{array}{c}70 \pm \\
0.090\end{array}$ & 162 & $\begin{array}{c}63 \pm \\
0.021\end{array}$ & 233 \\
\hline
\end{tabular}

Low value of wetting time and disintegration time indicates that the tablets porosity of batch F1 - $10 \mathrm{kN}$ would be greater than all other batches.

Tablets in F1 $(20 \mathrm{kN})$ with high mechanical resistance pass quality control, except friability $(1.48 \%)$.

Modified ratio of excipients Pharmaburst ${ }^{\mathrm{TM}} 500$ $80 \%$ and Avicel $1.14 \%$ didn't improve the quality parameters for fast dissolving tablets: friability, disintegration, wetting time (Tables 4 and 5).

The $10 \mathrm{kN}$ compression force and Pharmaburst ${ }^{\mathrm{TM}}$ $50070 \%$ (F1) have resulted in decreased disintegration time in optimum correlation to friability, hardness, and wetting time (Table 4 and Table 5).

\section{Conclusions}

Co-processed Pharmaburst ${ }^{\mathrm{TM}} 500$ excipient $70 \%$ at $10 \mathrm{kN}$ compression force used for $25 \mathrm{mg}$ diclofenac sodium ODTs obtaining determined good results for quality control tests evaluation (dimensional properties, friability, hardness, disintegration time, wetting time).

The formulation of diclofenac sodium $25 \mathrm{mg}$ ODTs with Pharmaburst ${ }^{\text {TM }} 500$ and other excipients that Avicel PH 102 could lead to better fast dissolving tablets.

It is thus concluded that, by adopting a systematic formulation approach, an optimum point can be reached in the shortest time with minimum efforts.

\section{References}

[1] S. E. Leucuța in Medicines modified release, ed. House book of science, Cluj - Napoca 2011, pp. 286-295 (in Romanian).

[2] A. Asthana, S. Aggarwal, and G. Asthana, Int. J. Pharm. Sci. Rev. Res. 20, 193 (2013).

[3] A.N. Cristea, Pharmacology treaty, first edition, Medical Publishing House, Bucharest 2013 (in Romanian).

[4] J. K. Tillotson, SpiPharma, Pharmaburst TM 500: optimized, evolutionary ODT performance, 2011. 
[5] M. Guhmann, M. Thommes, F. Gerber, N. Pöllinger, S. Klein, J. Breitkreutz, and W. Weitschies, Pharm. Res. 30, 1483 (2013).

[6] C. A. Lipinski, F. Lombardo, B. W. Dominy, and P. J. Feeney. Advanced Drug Delivery Reviews 23, 3 (1997).

[7] ***, Romanian Pharmacopoeia, $10^{\text {th }}$ edition, Medical Publishing House, Bucharest 2011 (in Romanian).

[8] http://pubchem.ncbi.nlm.nih.gov/compound/30 33

[9] K. Kashniyal, A.N. Choudhary, P. Kothiyal, Int. J. Ph. Ch. Sci. 2, 82 (2013).

[10] J. M. Suñé-Negre, M. Roig, R. Fuster, C. Hernández, R. Ruhí, E. García-Montoya, P. Pérez-Lozano, M. Miñarro, J.R. Ticó -
International Journal of Pharmaceutics 470, 15 (2014).

[11] D.S. Nikam and V. Kadam, International Journal of Pharmacy \& Pharmaceutical Research 5, 82 (2015).

[12] ***, European Pharmacopoeia 8.0. EDQM, 2014.

[13] P. Khokhar, V. Shukla - Formulation and evaluation of fast dissolving tablets of diclofenac sodium using PVP, Int. J. of Pharma Res. \& Rev. 3, 12 (2014).

Received: 17 March 2016 Received in revised form: 14 April 2016 Accepted: 01 May 2016 